\title{
Centipeda periodontii gen. nov., sp. nov. from Human Periodontal Lesions
}

\author{
C.-H. LAI, B. M. MALES, P. A. DOUGHERTY, P. BERTHOLD, AND M. A. LISTGARTEN \\ University of Pennsylvania Center for Oral Health Research and School of Dental Medicine, Philadelphia, \\ Pennsylvania 19104
}

\begin{abstract}
Nine strains of motile, anaerobic, nonsporeforming, gram-negative bacteria were isolated from human lesions of adult and juvenile periodontitis and compared with type strains Fusobacterium plauti ATCC 29863, Selenomonas sputigena ATCC 33150, Selenomonas ruminantium ATCC 12561, and Pectinatus cerevisiiphilus ATCC 29359. The cells of our isolates were long and serpentine and appeared to be bilaterally flagellated when they were examined by dark-field microscopy, giving the cells a centipede-like appearance. Electron microscopic studies showed the presence of a linear zone of flagellar insertions which spiraled around the cell body. Cultures were fermentative and produced propionic, acetic, lactic, and succinic acids. The guanine-plus-cytosine contents of the deoxyribonucleic acids of three isolates ranged from 52 to $54 \mathrm{~mol} \%$, as determined by the thermal denaturation method. All strains had 58 to $100 \%$ deoxyribonucleic acid homology with one another, but only $14 \%$ or less homology with the deoxyribonucleic acids of three previously described species. We propose the name Centipeda periodontii gen. nov., sp. nov. for these organisms; strain LL2383 (= ATCC 35019 ) is the type strain.
\end{abstract}

We isolated several strains of relatively large, anaerobic, motile, rod-shaped bacteria from subgingival lesions of patients with periodontitis. Isolates having similar morphologies were obtained frequently from samples taken from diseased sites, but not from samples from healthy sites. In their characteristics these isolates resembled the original description of Fusobacterium plauti (Eubacterium plautii [6]) (10). We compared our isolates with the type strains of $F$. plauti, Selenomonas sputigena, Selenomonas ruminantium and Pectinatus cerevisiiphilus, the species which they most closely resembled. Our results indicate that the new isolates should be assigned to a new genus and species, for which we propose the name Centipeda periodontii.

(Some of the results were presented at the 60th Session of the International Association for Dental Research, New Orleans, La., March 1982 , abstr. no. 474 , where the organism described in this paper was described as Centipeda orale.)

\section{MATERIALS AND METHODS}

Culture isolation. Isolates were obtained from subgingival scrapings from two patients (ages, 41 and 42 years) with adult periodontitis and three patients (ages, 12, 12, and 17 years) with localized juvenile periodontitis.

Microbial sampling. Subgingival debris was collected with a sterile periodontal curette (Gracey type
11/12) and immediately transferred to a prereduced dispersion medium (15) modified to contain fullstrength Ringer solution without sodium metaphosphate and a final resazurin concentration of $7.5 \times$ $10^{-7} \%$. The samples were dispersed anaerobically with a modified glass tissue homogenizer and serially diluted in prereduced dispersion medium, and $0.1-\mathrm{ml}$ portions were plated onto Trypticase-soy agar containing 5\% sheep blood (BBL Microbiology Systems, Cockeysville, $\mathrm{Md}$.). The plates were incubated at $35^{\circ} \mathrm{C}$ in an anaerobic chamber containing an $80 \% \mathrm{~N}_{2}-10 \%$ $\mathrm{CO}_{2}-10 \% \mathrm{H}_{2}$ atmosphere for 5 to 7 days. Individual colonies were selected for examination by dark-field microscopy and subcultured onto blood agar plates.

Reference strains. Type strains $S$. sputigena ATCC $33150, S$. ruminantium ATCC 12561 , and $F$. plauti ATCC 29863 (E. plautii) were obtained from the American Type Culture Collection, Rockville, Md. All reference strains were grown anaerobically in Socransky complex broth for gram-negative anaerobes, which contained $10 \mathrm{~g}$ of trypticase, $5 \mathrm{~g}$ of yeast extract. $3 \mathrm{~g}$ of beef extract, $5 \mathrm{~g}$ of glucose, $1 \mathrm{~g}$ of sodium nitrate, $2 \mathrm{~g}$ of sodium pyruvate, $0.1 \mathrm{~g}$ of sodium succinate, 5 $\mathrm{mg}$ of hemin, $1 \mathrm{~g}$ of sodium formate, $1.5 \mathrm{~g}$ of sodium fumarate, $0.5 \mathrm{ml}$ of Tween $80,1 \mathrm{ml}$ of resazurin $(0.025 \%), 10 \mathrm{ml}$ of VPI salt solution (7), $0.5 \mathrm{~g}$ of cysteine, and $0.5 \mathrm{mg}$ of vitamin $\mathrm{K}_{3}$ (menadione) in $1,000 \mathrm{ml}$ of broth adjusted to $\mathrm{pH} 7.0$ to 7.2 with $1 \mathrm{~N}$ sodium hydroxide.

Culture and maintenance. All strains were maintained by weekly subculture on blood agar plates. Isolates on agar were stored in liquid nitrogen on slabs from blood agar plates in Socransky complex broth supplemented with $5 \%$ dimethyl sulfoxide. Cultures grown in brain heart infusion-supplemented medium 


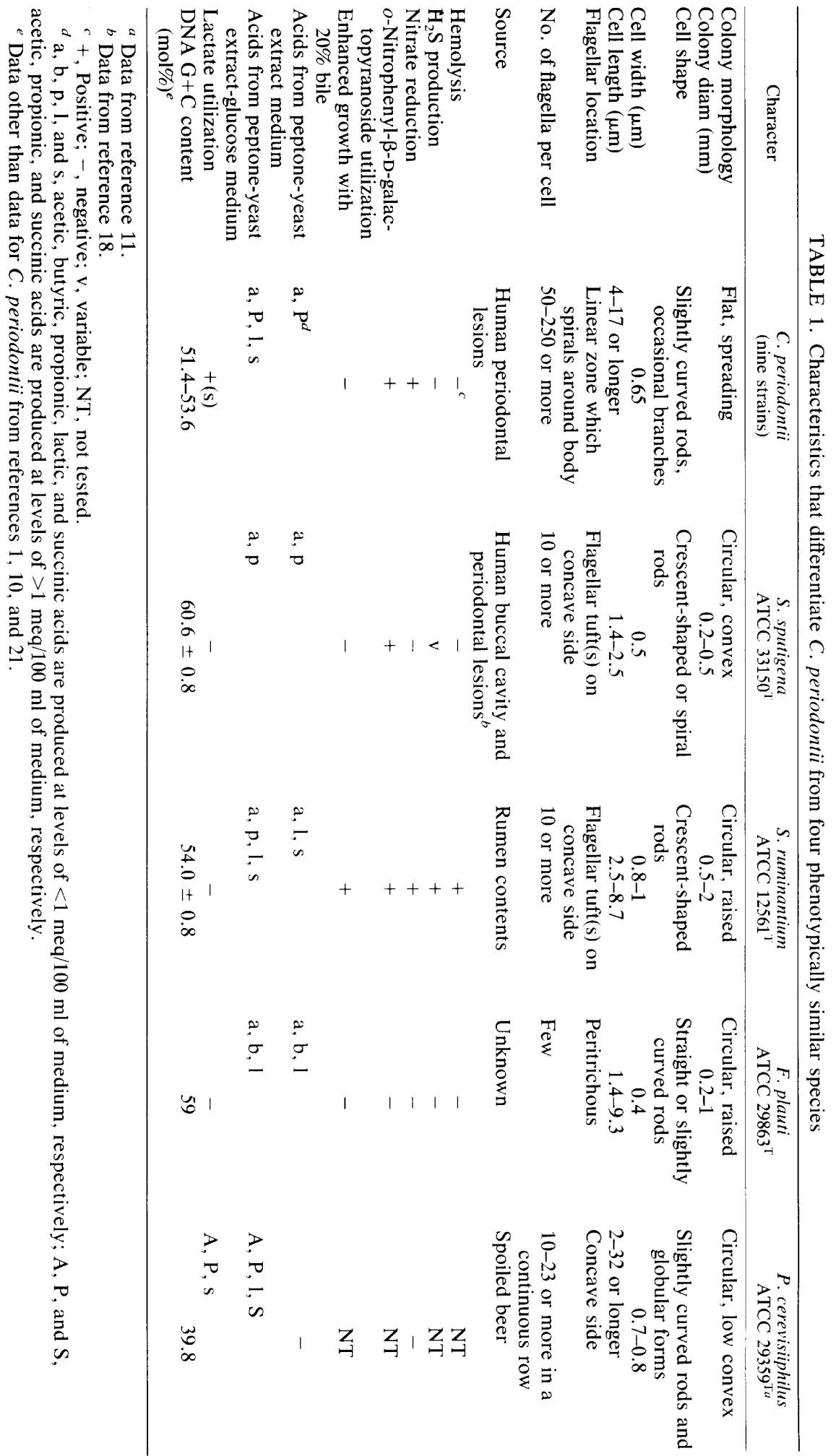



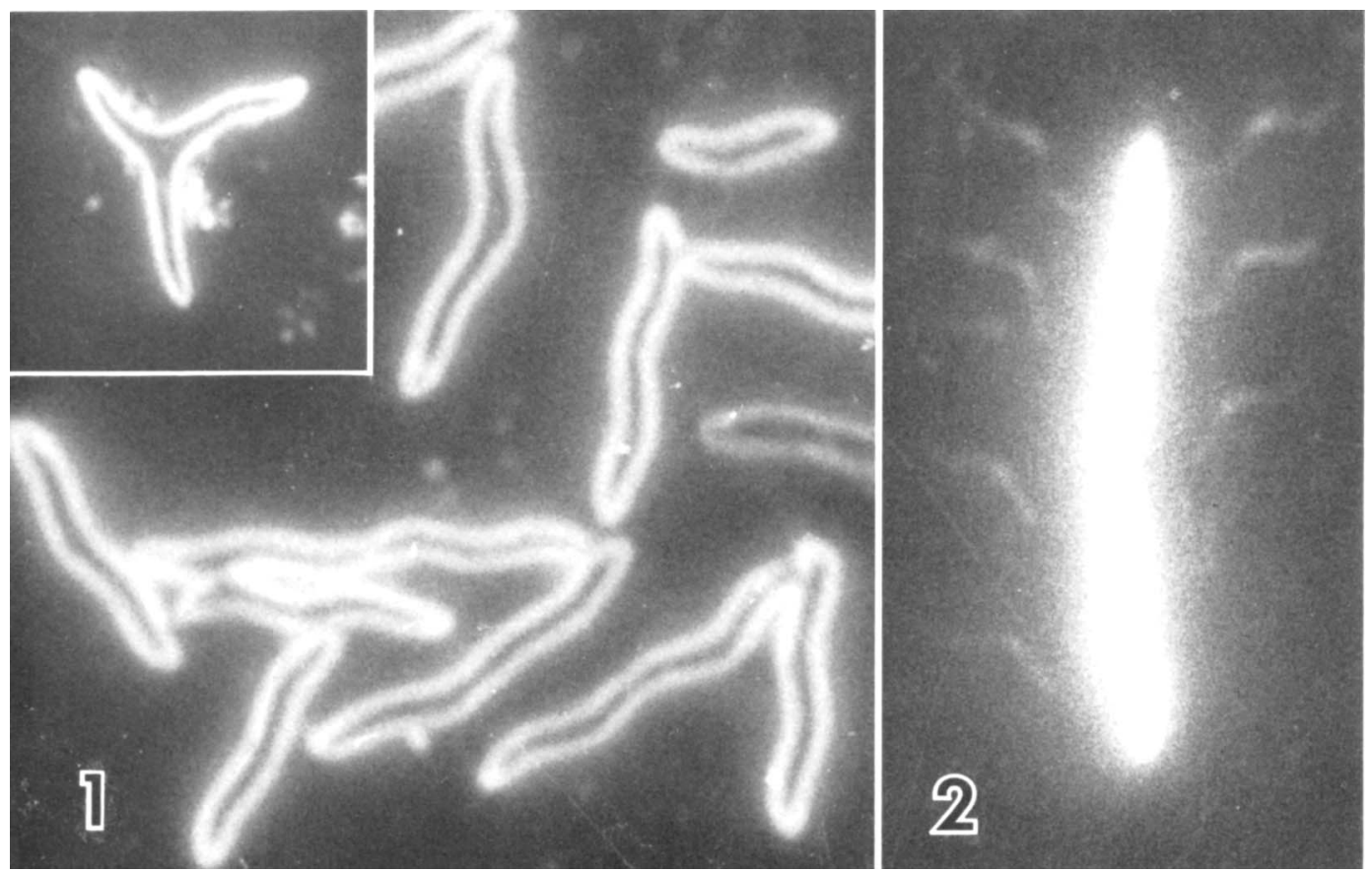

FIG. 1. Dark-field microscopy of a 3-day-old blood agar culture of $C$. periodontii strain LL2021 (first passage). $\times 7,700$. The inset shows a branching cell after repeated passages $(\times 4,700)$.

FIG. 2. Dark-field microscopy of a 2-day-old broth culture of $C$. periodontii strain LL2383 ${ }^{\mathrm{T}}$ (second passage). $\times 7,700$.

(7) were lyophilized in brain heart infusion-supplemented medium containing $12 \%$ sucrose. For inocula or mass cultures, all isolates were grown anaerobically in Todd-Hewitt broth (BBL).

Physiological and biochemical characterization. Growth in different atmospheres was tested by incubating blood agar plates either aerobically at $35^{\circ} \mathrm{C}$, with a carbon dioxide GasPak (BBL) in an anaerobe jar (BBL) at $35^{\circ} \mathrm{C}$, or anaerobically as described previously. Carbohydrate-containing media $(10 \mathrm{ml}$ each) were inoculated with $0.5-\mathrm{ml}$ portions of an actively growing, 4-day-old culture in peptone-yeast extract basal medium (7). The carbohydrate broth media were incubated anaerobically for 4 days. Uninoculated broth media were used as controls. Most characteristics were determined by the methods of Holdeman et al. (7). Production of oxidase, urease, and hydrogen sulfide, gelatin liquefaction, and the presence of betagalactosidase were tested with the Minitek system (BBL). Hemolysis was determined on plates containing Trypticase-soy agar supplemented with 5\% sheep blood. Volatile and nonvolatile fatty acid products were determined by the method of Salanitro and Muirhead (22).

Microscopy. For dark-field microscopy, cells from 3day-old cultures on blood agar plates were suspended in water; 2-day-old Todd-Hewitt broth cultures were also examined directly in broth. The slides were photographed with a Zeiss Photomicroscope at a film magnification of $\times 560$, with subsequent photographic enlargement.
For transmission electron microscopy, cells from 3day-old blood agar plate cultures were fixed in $5 \%$ glutaraldehyde and $4 \%$ paraformaldehyde buffered to pH 7.3 with sodium cacodylate (9). After postfixation in $2 \%$ s-collidine-buffered osmic acid, the cells were washed, dehydrated in graded ethanol solutions, and embedded in Epon (13). Sections $(0.1 \mu \mathrm{m})$ were cut, mounted on bare grids, and stained with uranyl acetate and lead citrate (20). Negatively stained preparations were obtained by applying 1 drop of cellular material suspended in $2 \%$ phosphotungstic acid onto a carbonreinforced, Formvar-coated grid. The excess liquid was blotted off, and the preparation was air dried. Cell length was determined from dark-field micrographs. Cell diameter was measured from electron micrographs of cellular cross-sections. Measurements were taken from 10 to 30 cells per strain.

DNA preparation. Purified deoxyribonucleic acid (DNA) from each isolate and reference strain was prepared by the methods of Marmur (16) and Edelman (4). Labeled DNA was prepared by the in vitro nicktranslation method (21), using a commercially prepared nick-translation reagent kit (Bethesda Research Laboratories, Inc., Gaithersburg, Md.) and deoxycytidine $5^{\prime}-\left[\alpha-{ }^{32} \mathrm{P}\right]$ triphosphate (triethylammonium salt; Amersham Corp., Arlington Heights, III.) as the radiolabeled nucleotide.

The percentage of DNA-DNA duplex formation between homologous DNA and heterologous DNA was determined for each test and reference strain by the S1 endonuclease method of Crosa et al. (2). The 


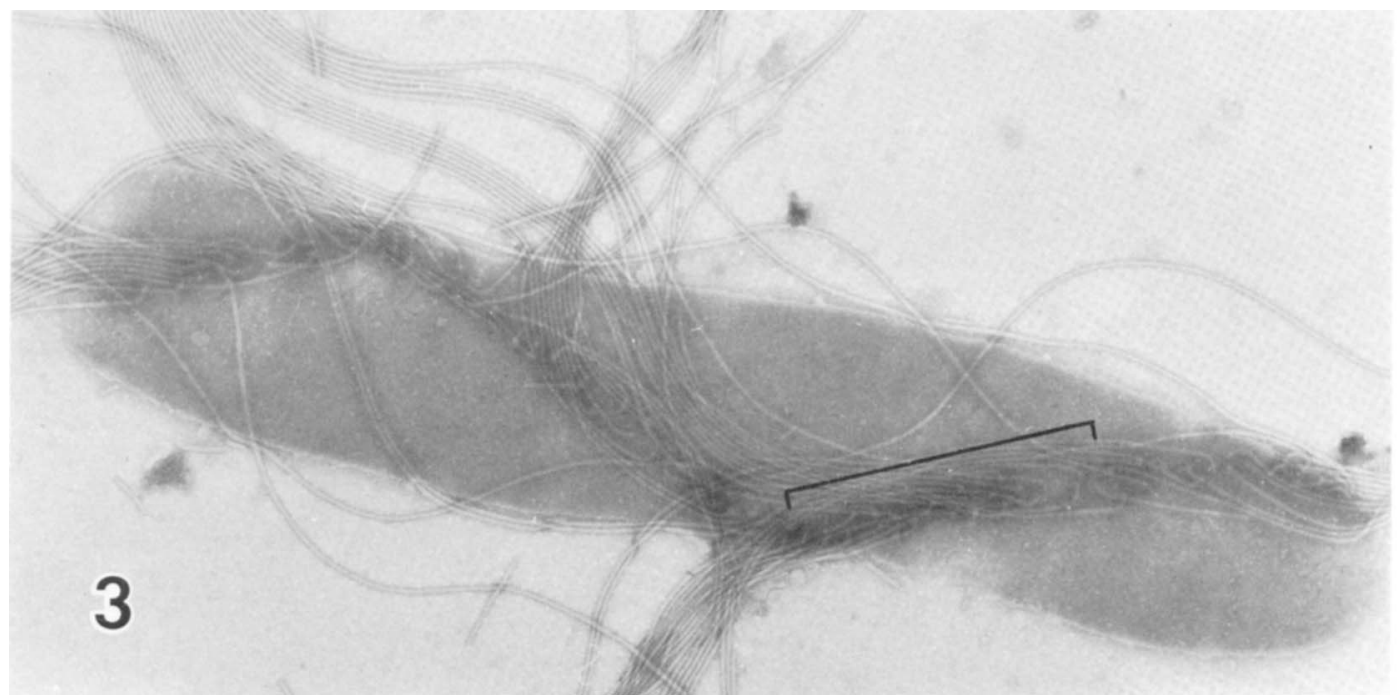

FIG. 3. Negatively stained preparation of a lysed cell, showing the spiral path of the flagellar insertions (bracket). $\times 32,800$.

guanine-plus-cytosine $(\mathrm{G}+\mathrm{C})$ content of each DNA preparation was computed from a comparison of the thermal denaturation value of the test DNA and the thermal denaturation value of reference Escherichia coli K-12 type VIII DNA (Sigma Chemical Co., St. Louis, Mo.), which was obtained in each run (14).

\section{RESULTS AND DISCUSSION}

The nine isolates which we studied are homogeneous in the properties that distinguish them from the reference species included in this investigation (Table 1). The cells of these isolates are characterized by a centipede-like appearance, which is derived from the many sets of flagellar bundles that arise from both sides of the cells (Fig. 2 and 4). The flagella are inserted along a linear zone which spirals around the cell body (Fig. 3). The Selenomonas and Pectinatus species have flagella only on one side, and $F$. plauti (E. plautii) possesses few flagella, which are detected only by electron microscopy.

Early descriptions of some peritrichous bacilli $(5,19)$, including the original $F$. plauti strains $(10,23,24)$, closely resemble the description of our isolates. However, none of the original strains are available for comparison. Although our isolates may well correspond to the strains described in these previous studies, they are clearly distinguished from $F$. plauti ( $E$. plautii) by their failure to produce butyric acid. $P$. cerevisiiphilus closely resembles our isolates in morphology and acid products, but it can be readily distinguished from our strains by the arrangement of its flagella (11). Although the $\mathrm{G}+\mathrm{C}$ contents of DNAs from three isolates are similar to the value reported for $S$. ruminantium, they can be distinguished from the $\mathrm{G}+\mathrm{C}$ contents reported for $S$. sputigena, $F$. plauti $(E$. plautii), and $P$. cerevisiiphilus.

On the basis of the distinctive arrangement of the flagella, we have assigned our new isolates to a new genus and species in the family Bacteroidaceae (8), as described below.

Centipeda gen. nov. Centipeda (Cen.ti'pe.da. L. fem.n. centipeda a centipede [12]) cells are anaerobic, gram-negative, nonsporeforming, serpentine, and rod-shaped with three or more curves. Motile by means of flagella inserted in a spiral path along the cell body (Fig. 3). Movement occurs by flexion of the entire cell and rotation around its long axis. Spores are not produced.

Chemoorganotrophic. Saccharoclastic. Propionic acid is a major product; variable smaller amounts of acetic, succinic, or lactic acid are produced from carbohydrates.

The $\mathrm{G}+\mathrm{C}$ content of the type species is 53 mol\%. The type species is Centipeda periodontii sp. nov. (per.i.o.don'ti.i. M.L. n. [T.Gr.] periodontium periodontium; M.L. gen.n. periodontii of the periodontium).

Centipeda periodontii sp. nov. (i) Cellular morphology and ultrastructure. Cells of freshly isolated strains are gram negative, slightly serpentine, long, and rod-shaped with three or more curves and bluntly tapered ends (Fig. 1, 2, and 4). The amount of cell curvature is variable among strains and is reduced after repeated passage in culture. The cell diameter is $0.65 \mu \mathrm{m}$, and the cell length ranges from 4 to $17 \mu \mathrm{m}$ or longer in older cultures. The cells occur singly or occasionally in chains; occasional budding gives 

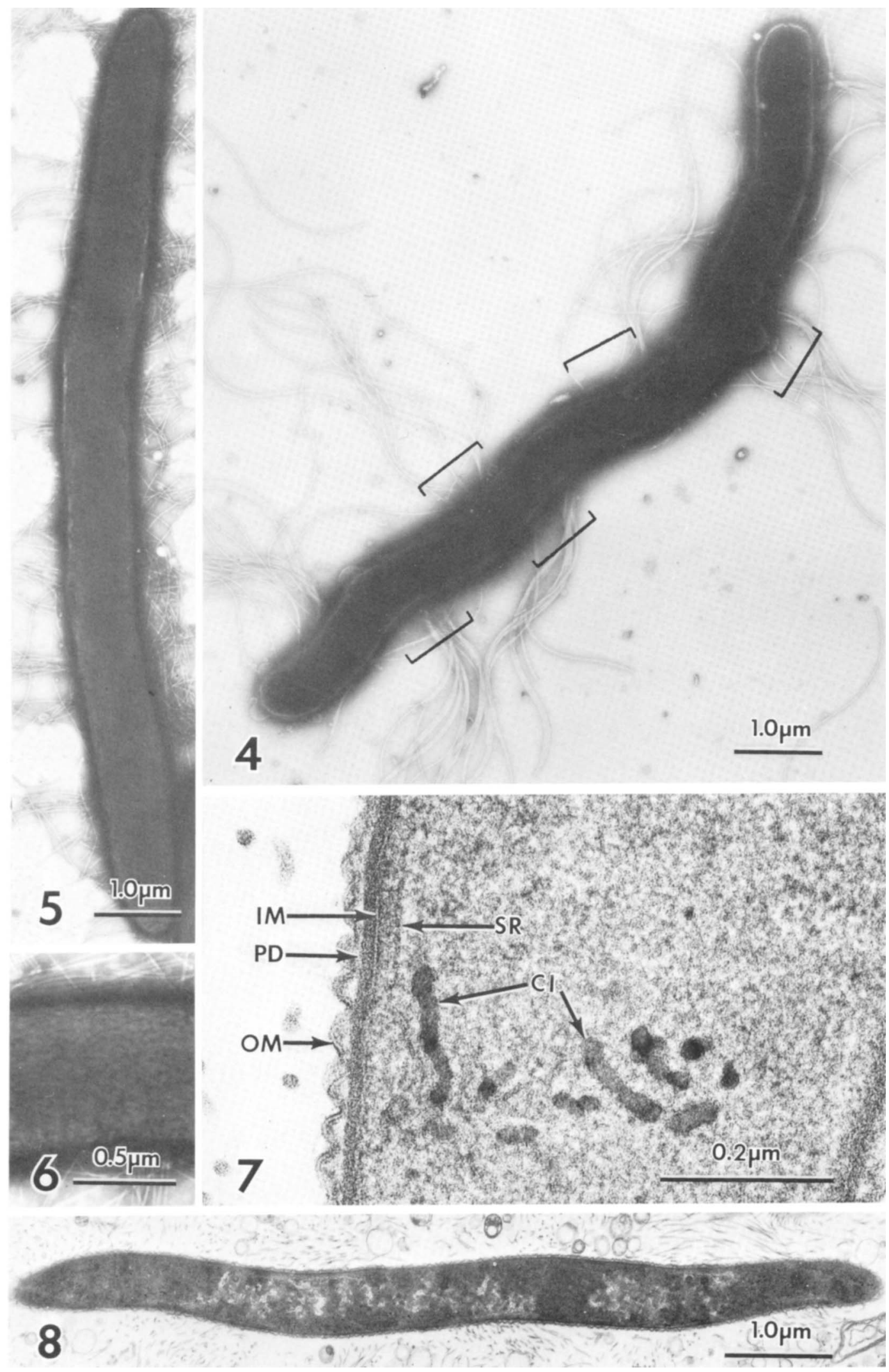


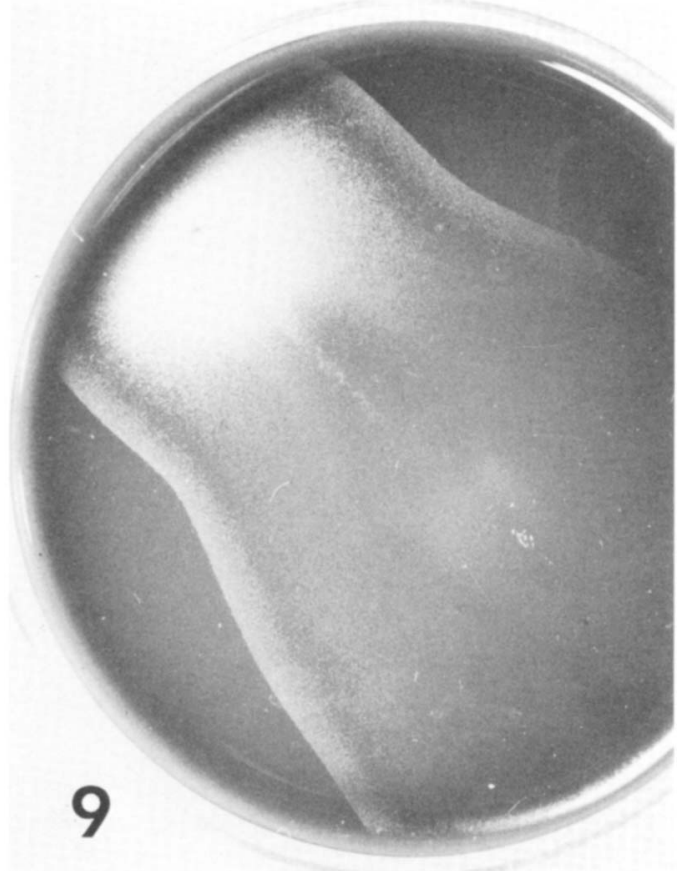

FIG. 9. C. periodontii strain $\mathrm{LL} 2383^{\mathrm{T}}$ 1-day-old colony on blood agar, showing rapid spreading. $\times 0.9$.

rise to branched forms (Fig. 1). Multiple sets of flagellar bundles are present on each side of the cell. The number of flagellar bundles increases with increasing cell length. The bundles originate alternately from the concave areas along the curved cell body (Fig. 2 and 4). Higher magnifications of negatively stained cells show a spiral path of insertion of the individual flagella from which the bundles are formed (Fig. 3). This flagellar pattern is distinct from the one-sided patterns of Selenomonas (1) and Pectinatus (11) species.

Cells in 24-h broth cultures are actively motile. Motility is accompanied by flexion of the entire cell in a snakelike motion and by rotation around the long axis of the cell body. Tumbling
TABLE 2. Characteristics that vary among strains of $C$. periodontii

\begin{tabular}{lcc}
\hline \multicolumn{1}{c}{ Test } & $\begin{array}{c}\text { Reaction of } \\
\text { type strain } \\
\text { ATCC } 35019\end{array}$ & $\begin{array}{c}\text { No. of strains } \\
\text { positive }\end{array}$ \\
\hline Adonitol & $\mathrm{A}^{a}$ & 7 \\
Cellobiose & - & 1 \\
Mannose & - & 6 \\
Melezitose & - & 8 \\
Rhamnose & - & 4 \\
Salicin & - & 4 \\
Trehalose & - & 8 \\
Xylose & - & 1 \\
Hydrolysis of esculin & - & 7 \\
\hline
\end{tabular}

${ }^{a} \mathrm{~A}, \mathrm{pH} \leq 5.5 ;-, \mathrm{pH} \geq 6.0$.

is observed occasionally. Changes in direction of motility are preceded by a period of twitching motion in which the cells are nearly stationary; the flagellar bundles of the cells are fully extended and rotate erratically. In 5-day broth cultures few cells are motile, and cytoplasmic granules are visible when cells are examined by dark-field microscopy.

Negatively stained preparations of cell surfaces exhibit the typical brainlike contour reported for many other gram-negative bacteria (Fig. 5 and 6). Cellular cross-sections reveal a typical gram-negative cell wall structure (Fig. 7 and 8 ). The outer and inner membranes consist of two electron-dense layers separated by an electron-lucent layer. The outer membrane has an irregular, undulating profile, whereas the cytoplasmic membrane is relatively smooth and in direct contact with the moderately electrondense peptidoglycan layer. Nucleoid areas are dispersed throughout the cytoplasm, which contains rod-shaped, electron-dense inclusions (Fig. 7). Specialized regions of the peripheral cytoplasm approximately 30 by 130 to $220 \mathrm{~nm}$ occur along the inner membrane (Fig. 7).

(ii) Cultural characteristics. During initial isolation on blood agar, strains form flat, tranparent colonies approximately $2 \mathrm{~mm}$ in diameter with irregular borders. After subculturing, the colo-

FIG. 4. Negatively stained preparation of a 2-day-old broth-grown cell. The flagellar tufts (brackets) consist of bundles of 10 or more flagella. $\times 13,800$.

FIG. 5. Negatively stained preparation of a 3-day-old blood agar culture. $\times 13,800$.

FIG. 6. Higher magnification of a negatively stained preparation of a 3-day-old blood agar culture, showing the typical surface contour of gram-negative cells. $\times 32,800$.

FIG. 7. Sectioned cell. OM, Outer membrane; PD, peptidoglycan layer; IM, inner membrane; SR, specialized cytoplasmic regions; CI, cytoplasmic inclusions. $\times 136,000$.

FIG. 8. Sectioned cell, showing the serpentine shape and numerous sectioned flagella. $\times 17,000$. 
TABLE 3. DNA hybridization data for $C$. periodontii and reference species

\begin{tabular}{|c|c|c|c|c|}
\hline \multirow[b]{2}{*}{ Source of unlabeled DNA } & \multicolumn{4}{|c|}{$\%$ Hybridization with labeled DNA from: } \\
\hline & $\begin{array}{l}\text { C. periodontii } \\
\text { LL2383 }^{\mathrm{T}}\end{array}$ & $\begin{array}{l}\text { C. periodontii } \\
\text { LL2021 }\end{array}$ & $\begin{array}{c}F \cdot \text { plauti } \\
\text { ATCC } 29863^{\mathrm{T}}\end{array}$ & $\begin{array}{l}\text { S. sputigena } \\
\text { ATCC } 33150^{\mathrm{T}}\end{array}$ \\
\hline \multicolumn{5}{|l|}{ C. periodontii } \\
\hline LL2383 & 100 & 88 & 2 & 5 \\
\hline LL2381 & 94 & 72 & $<1$ & 2 \\
\hline LL2021 & 78 & 100 & 6 & 5 \\
\hline LL2022 & 86 & 91 & 4 & 6 \\
\hline LL2473 & $86(v)^{a}$ & $87(\mathrm{v})$ & 6 & 3 \\
\hline LL2474 & $86(v)$ & $82(\mathrm{v})$ & 14 & 4 \\
\hline LL2465 & $71(v)$ & $69(\mathrm{v})$ & 2 & 2 \\
\hline LL2467 & $66(v)$ & $62(v)$ & $<1$ & $<1$ \\
\hline LL2441 & $70(v)$ & $58(v)$ & 11 & 2 \\
\hline$F$. plauti ATCC $29863^{\mathrm{T}}$ & 10 & 7 & 100 & 6 \\
\hline S. sputigena ATCC $33150^{\mathrm{T}}$ & 11 & 12 & 2 & 100 \\
\hline S. ruminantium ATCC $12561^{\mathrm{T}}$ & 9 & 7 & 3 & 3 \\
\hline
\end{tabular}

${ }^{a}(\mathrm{v})$, Variable results (Values represent the maximum percent hybridization values from eight determinations).

nies are gray, transparent, and flat or thinly raised with finely granular surfaces (Fig. 9). Growth spreads rapidly and after 3 days of incubation covers the entire surface of a plate.

Growth in broth is turbid, forming a dense, white, sediment which may be 2 to $3 \mathrm{~cm}$ deep after $24 \mathrm{~h}$.

(iii) Physiological and biochemical characteristics. Cultures grow on complex media (e.g., blood agar and Todd-Hewitt broth). The organisms are strict anaerobes and produce no growth aerobically or in atmospheres containing increased concentrations of $\mathrm{CO}_{2}$. Growth occurs between 32 and $37^{\circ} \mathrm{C}$; the optimum temperature is $35^{\circ} \mathrm{C}$. Growth is not enhanced by bile. The addition of a fermentable carbohydrate to a broth culture enhances growth. Acid without gas is produced from the fermentation of carbohydrates. All strains ferment fructose, galactose, glucose, lactose, maltose, mannitol, melibiose, raffinose, sorbitol, and sucrose. Fermentation of adonitol, cellobiose, mannose, melezitose, rhamnose, salicin, trehalose, and xylose is variable among strains (Table 2). Amygdalin, arabinose, dulcitol, esculin, glycogen, inositol, inulin, sorbose, and starch are not fermented. Starch is not hydrolyzed; esculin hydrolysis varies among strains. Arginine is not utilized. The final $\mathrm{pH}$ in peptone-yeast extract broth containing $1 \%$ glucose is 4.2 to 5.0 .

C. periodontii strains produce 1.2 and $2.2 \mathrm{meq}$ of propionic acid per $100 \mathrm{ml}$ of medium in peptone-yeast extract broth and peptone-yeast extract-glucose broth, respectively; smaller amounts of succinic acid and lactic acid are also produced. Lactate may be converted to succinate.

Catalase, oxidase, urease, $\mathrm{H}_{2} \mathrm{~S}$, and indole are not produced. Nitrate is reduced, and $o$-nitro- phenyl- $\beta$-D-galactopyranoside is utilized. Propionate is not produced from threonine, gelatin is not liquified, and no hemolysis occurs on sheep blood agar.

The pathogenicity of $C$. periodontii has not been determined, although members of this species have been isolated from human periodontal lesions and have not been detected in healthy subjects. The $\mathrm{G}+\mathrm{C}$ content of the DNA of the type strain is $53 \mathrm{~mol} \%$, as determined by the thermal denaturation method; the $\mathrm{G}+\mathrm{C}$ contents of two other strains tested are 52 and $54 \mathrm{~mol} \%$. The type strain is LL2383, which has been deposited in the American Type Culture Collection as ATCC 35019.

(iv) DNA sequence homology and base composition. We compared nine strains of $C$. periodontii with the type strains of $F$. plauti (E. plautii), $S$. sputigena, and $S$. ruminantium by a sequence homology test (Table 3 ) and found no measurable homology among the four species. Erratic and unusually low DNA hybridization values occurred among some strains of $C$. periodontii. Our difficulty in obtaining reliable hybridization data for some strains probably reflects differences among the isolates in the proportions of contaminating material (most likely polysaccharide, which remains behind in purified DNA preparations [3]). However, repeated attempts to extract DNAs of greater purity from these isolates did not improve the reproducibility of our results.

In view of the morphological and biochemical data, as well as the similarities in DNA G+C contents, we placed all nine of our strains in the same species.

Characteristics that may help differentiate some phenotypically similar species are shown in Table 1. 


\section{ACKNOWLEDGMENTS}

We are grateful to Rollande Tremblay for excellent technical assistance.

This work was supported by Public Health Service grants DE-02623 and R01-DE-04759 from the National Institute of Dental Research. B.M.M. and P.B. were supported by Public Health Service training grant 5T-32-DE-07085 from the National Institute of Dental Research.

\section{LITERATURE CITED}

1. Bryant, M. P. 1974. Genus Selenomonas, p. 424-426. In R. E. Buchanan and N. E. Gibbons (ed.), Bergey's manual of determinative bacteriology, 8th ed. The Williams \& Wilkins Co., Baltimore.

2. Crosa, J. H., D. T. Brenner, and S. Falkow. 1973. Use of a single-strand-specific nuclease for analysis of bacterial and plasmid deoxyribonucleic acid homo- and heteroduplexes. J. Bacteriol. 115:904-911.

3. De Ley, J., and R. Tijtgat. 1970. Evaluation of membrane filter methods for DNA-DNA hybridization. Antonie van Leeuwenhoek J. Microbiol. Serol. 36:461-474.

4. Edelman, M. 1975. Purification of DNA by affinity chromatography: removal of polysaccharide contaminants. Anal. Biochem. 65:293-297.

5. Gins, H. A. 1934. Die nichtversporenden Anaerobier der Mundhöhle und der Zähne. Zentralbl. Bakteriol. Parasitenkd. Infektionskr. 132:129-145.

6. Hofstad, T., and P. Aasjord. 1982. Eubacterium plautii (Séguin 1928) comb. nov. Int. J. Syst. Bacteriol. 32:346349.

7. Holdeman, L. V., E. P. Cato, and W. E. C. Moore. 1977. Anaerobe laboratory manual, 4th ed. Virginia Polytechnic Institute and State University Anaerobe Laboratory, Blacksburg.

8. Holdeman, L. V., and W. E. C. Moore. 1974. Family I. Bacteroidaceae, p. 384. In R. E. Buchanan and N. E. Gibbons (ed.). Bergey's manual of determinative bacteriology, 8th ed. The Williams \& Wilkins Co., Baltimore.

9. Karnovsky, M. J. 1965. A formaldehyde-glutaraldehyde fixative of high osmolarity for use in electron microscopy. J. Cell Biol. 27:137A-138A

10. Kritchevsky, B., and P. Séguin. 1921. Traitement des spirochétoses buccales (pyorrhée alveolaire) par les préparations arsenicales. L'Odontologie 59:720-742.

11. Lee, S. Y., M. S. Mabee, and N. O. Jangaard. 1978.
Pectinatus, a new genus of the family Bacteroidaceae. Int. J. Syst. Bacteriol. 28:582-594.

12. Lewis, C. T., and C. Short. 1966. Latin dictionary. Oxford University Press, London.

13. Luft, J. H. 1961. Improvement in epoxy resin embedding methods. J. Biophys. Biochem. Cytol. 9:409-414.

14. Mandel, M., L. Igambi, J. Bergendahl, M. L. Dodson, Jr., and E. Scheltgen. 1970. Correlation of melting temperature and cesium chloride buoyant density of bacterial deoxyribonucleic acid. J. Bacteriol. 101:333-338.

15. Manganiello, A. D., S. S. Socransky, C. Smith, D. Propas, V. Oram, and I. L. Dogon. 1977. Attempt to increase viable count recovery of human supragingival dental plaque. J. Periodontal Res. 12:107-119.

16. Marmur, J. 1961. A procedure for the isolation of deoxyribonucleic acid from microorganisms. J. Mol. Biol 3:208-218.

17. Moore, W. E. C., and L. V. Holdeman. 1974. Genus II. Fusobacterium, p. 404-416. In R. E., Buchanan and N. E. Gibbons (ed.), Bergey's manual of determinative bacteriology, 8th ed. The Williams \& Wilkins Co., Baltimore.

18. Moore, W. E. C., L. V. Holdeman, R. M. Smibert, D. E. Hash, J. A. Burmeister, and R. R. Ranney. 1982. Bacteriology of severe periodontitis in young adult humans. Int. J. Sys. Bacteriol. 38:1137-1148.

19. Mühlens, P. 1909. Uber Züchtung von anaëroben Mikroorganismen der Mundhöhle (u.a. Spirillum sputigenum). Zentralbl. Bakteriol. Parasitenkd. Infektionskr. 48:523-528.

20. Reynolds, E. S. 1963 . The use of lead citrate at high pH as an electron-opaque stain in electron microscopy. J. Cell Biol. 17:208-212.

21. Rigby, P. W. J., M. Dieckmann, C. Rhodes, and P. Berg. 1977. Labeling deoxyribonucleic acid to high specific activity in vitro by nick translation with DNA polymerase I. J. Mol. Biol. 113:237-251.

22. Salanitro, J. P., and P. A. Muirhead. 1975. Quantitative method for the gas chromatographic analysis of shortchain monocarboxylic and dicarboxylic acids in fermentation media. Appl. Microbiol. 29:374-381.

23. Sebald, M. 1962. Etude sur les bactéries anaérobies gramnégatives asporulées. Imprimerie Barneoud, S.A., Laval France.

24. Séguin, P. 1928. Culture du Fusobacterium plauti, forme mobile du bacille fusiforme. C. R. Seances Soc. Biol. Paris 99:439-442. 